\title{
THE EFFECTIVENESS \\ OF SOUTH SUMATRA COFFEE (Coffea arabica L.) EXTRACT CREAM IN BURN WOUND RECOVERY OF MALE WHITE MICE (Mus musculus)
}

\author{
Muhammad Romadhon $^{1 *}$, Dani Prasetyo ${ }^{2}$ \\ ${ }^{1}$ Faculty of Midwifery and Nursing, University of Kader Bangsa, J1. HM, Ryacudu No. 88 \\ Palembang, 30452, Indonesia \\ ${ }^{2}$ Faculty of Pharmacy, University of Kader Bangsa, Jl. HM, Ryacudu No. 88 Palembang, 30452, \\ Indonesia
}

Received December 12, 2020; Accepted January 12, 2021

\begin{abstract}
The effectiveness of South Sumatra coffee extract cream in burn wound recovery of white male mice had been analyzed. This research aims to ensure which one between immature and mature coffee bean that was better to recover burn wounds of male white mice after 14-day testing. The prepared concentrations for both coffee beans were $0.1 \%, 0.2 \%$, and $0.3 \%$. We then figured out that ethanol contained by young and old coffee beans had a recovery effect on burn wounds of male white mice (Mus musculus). Findings indicate that $0.3 \%$ of mature coffee beans were more effective in recovering burn wounds of male white mice (Mus musculus), in which the wound recovery percentage was close to that in the positive control (burnazin).
\end{abstract}

Keywords: burn wound; coffe extract; cream.

\section{INTRODUCTION}

Burn wounds constituted tissue damage or loss due to contacting a high-temperature source (e.g., fire, boiled water, chemicals, electricity, and radiacal (Nugroho, 2012) The prevalence of burn wounds in Indonesia was $0.7 \%$, which had declined by $1.5 \%$ fromthat in 2008 (2.2\%). Two provinces identified as having the highest prevalence are Papua (2.0\%) and Bangka Belitung (1,7\%). Despite the low prevalence, burn wounds were considered as a potentially global community health problem as it provoked high mortality and morbidity rates (1.4\%) (Depkes RI,2013).

Wound recovery is a process to recover the damage occurring. The primary principle of recovery was cooling the burn area down or reducing the inflames, preventing infections, and giving chances to the remnants of epithelial cells to proliferate and cover the wounds (Wirastuty, 2016).
The process of wound recovery comprises three phases, i.e., inflammation, proliferation, and maturation. The inflammatory phase was characterized by rubor (redness), color (heat), dolor (pain), and function laesa (loss of functions) (Sukmawati,2018).

One of the alternative home remedies is coffee powder. Coffee powder was renowned for its chlorogenic acid which reportedly had strong anti-oxidant and anti-bacterial effects, and served as a wound cover (Yuwono, 2014). Accordingly, coffee could be used to accelerate burn wound recovery (Muljana, 2010). We have found a myriad of empirical evidence which argues that the Indonesians have been using pure coffee powder as an alternative medicine to cure various types of wound, one of which is burn wound. Sudjono, in his research, attested that coffee powder demonstrated an anti-bacterial effect (Muljana, 2010).

*Corresponding author: Muhammad Romadhon

Email:madhon1989@gmail.com 
One of the dosage forms commonly distributed in markets is cream. Cream is a semi- solid dosage form of emulsion which contains water of not less than $60 \%$ and is intended for external use. The cream made in this research is the Oil or Water (O/A)-type cream. The selection of the type of cream is under the consideration that it is applied on the skin and thus expected to confer optimal effects because it elevates the gradient of the concentration of active substances which penetrate the skin and consequently enhances the percutaneous adsorption (Elmitra, 2017). Based on the explanation, we proved the effectiveness of ethanol extracted from coffee powder which had the ability to heal burn wounds or accelerate burn wound coverage. As such, we were interested in conducting a research entitled "The Effectiveness of South Sumatra Coffee (Caffea Arabica L.) Extract Cream in Burn Wound Recovery of Male White Mice (Mus musculus)".

\section{METHODS}

\section{Materials and instruments}

Mature and immature coffee powder, burnazin ointment, cetyl alcohol, stearic acid, triethanolamine, glycerin, methylparaben, aquadest, ethanol of $99 \%$ (Merck ${ }^{\circledR}$ ), Ketamine injection (generic $®$ ), rotary evaporator (IKA RV 10 basic), sieve 60 mesh, blender (Philips), pH meter (Hanna $\left.{ }^{\circledR}\right)$, analytical balance (Mettler toledo®), and glassware (pyrex®).

\section{Experimental animals}

Experimental animals used in this research were male white mice (Mus musculus) aged two months old, 20-30 grams in body weight, and had been acclimatized for seven days. The mice needed were 50 in number.

\section{Making coffee extract cream Simplicia making}

Prepare $5 \mathrm{~kg}$ of mature and immature coffee beans, wash them using clean water, and dry them under direct sunlight. When the beans had been dried, roast them until they were cooked and ground them using a blender to produce dried simplicial powder (Sembiring et al., 2015)

\section{Coffee extracting}

Extraction was conducted using a maceration method which consisted of the following steps. Take simplicia powder made of old and young coffee beans by 500 grams. Place each simplicial powder in a bottle or maceration vessel. Add liquid ethanol of $96 \%$ to the bottle or maceration vessel until the simplicial powder was entirely soaked. Close the bottle or maceration vessel and store it in a shadow place at room temperature for three days.

During the storage time, churn the bottle or maceration vessel repeatedly. Separate the pulp and filtrate. Re-extract the pulp using ethanol for three days. Repeat the soaking several times until the filtrate had been perfectly extracted. The filtrate extracted was evaporated using a rotary evaporator at $60^{\circ} \mathrm{C}$ until a thick extract was obtained. Calculate the yield based on Equation 1 (Paputungan et al., 2019).

Yield $=\underline{\text { weight } \text { of thick extract }(\mathrm{g}) \times 100 \%}$ weight of simplicia $(\mathrm{g})$

Table 1. Cream dosage formula

\begin{tabular}{clccc}
\hline No. & \multicolumn{1}{c}{ Ingredient } & FI $(\% \mathrm{~b} / \mathrm{b})$ & FII $(\% \mathrm{~b} / \mathrm{b})$ & FIII $(\% \mathrm{~b} / \mathrm{b})$ \\
\hline 1 & Extract & 0.1 & 0.2 & 0.3 \\
\hline 2 & Cetyl alcohol & 2 & 2 & 2 \\
\hline 3 & Stearic acid & 12 & 12 & 3 \\
\hline 4 & Triethanolamine & 3 & 3 & 8 \\
\hline 5 & Glycerin & 8 & 8 & 0.2 \\
\hline 6 & Methylparaben & 0.2 & 0.2 & $\mathrm{Ad} 100$ \\
\hline 7 & Aquades & Ad 100 & $\mathrm{Ad} 100$ & 3 \\
\hline
\end{tabular}




\section{Cream Making}

In cream making, we referred to Puspitasari et al., (2017) A thick extract ofarabica coffee was formulated into cream dosage at various extract concentrations namely FI $(0.1 \%)$, FII $(0.2 \%)$, and FIII $(0.3 \%)$. Cream making was performed by weighing each of the ingredients used. The oil phase was made by heating stearic acid and cetyl alcohol until they melted in a porcelain dish. During the heating process, we churned the two ingredients until they were homogenous at $70^{\circ} \mathrm{C}$ above a water bath. The water phase was conducted by dissolving triethanolamine, glycerin, methylparaben, and arabica coffee bean extract in a porcelain dish and stirring them over a water bath at $70^{\circ} \mathrm{C}$. Aquadest was heated over a water bath at a temperature of $70^{\circ} \mathrm{C}$. The water phase and the ethanol extract of the arabica coffee beans were transferred to a hot mortar and added to the oil phase, then stirred slowly. Distilled water was gradually added up to $100 \mathrm{~mL}$. The mixture of the oil phase and the water phase was stirred until cool, and a homogeneous cream mass was then formed. The formula for the respective cream of arabica coffee bean extract was tested for its chemical and physical properties.

\section{Characteristic test of the physical and chemical properties of cream}

The series of the test included the organoleptic test, homogeneity test, $\mathrm{pH}$ test, and spreadability test (Juwita et al., 2013; Murrkmihadi et al., 2012).

\section{Burn wound test}

The mice were weighed and randomly grouped into ten groups, each of which consisted of five mice. Five out of the ten groups were treated using young coffee extract, where as the five others were using the old one. Burn wounds were made using an iron plate at the size of a Rp 100.00 coin with a diameter of $23 \mathrm{~mm}$ which was previously heated in a Bunsen fire for one minute and contacted on the back of the mice for five seconds. Before their skin was burned, the mice were anesthetized using ketamine. The first group (either immature and matur coffee bean) was given FI cream, the second was given FII cream, the third was given FIII cream, the positive control group was given burnazin, and the negative control was given nothing. The medicine and coffee extract cream were evenly applied to the wound area of male white mice (Mus musculus) twice a day for 14 days. We observed the signs of wound recovery by measuring the wound area.

The wound area was measured using the

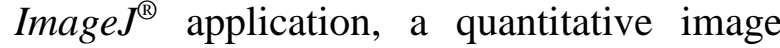
analysis tool used to measure a surface area. We compared the result of the daily observation of the respective mice by making a table of comparison. The time and percentage of burn wound healing were then converted into the recovery percentage $(\%)$ using "the Percentage Conversion Formula (Equation 2)" (Wijaya et al., 2014).

$$
\mathrm{P}_{\mathrm{x}}=\frac{\mathrm{d}_{1}{ }^{2}-\mathrm{d}_{x}^{2}}{\mathrm{~d}^{2}} \times 100 \%
$$

$$
\begin{array}{ll}
\mathrm{P}_{\mathrm{x}} & : \quad \begin{array}{l}
\text { Percentage of healing on } x \text { day(in } \\
\%)
\end{array} \\
\mathrm{d} 1 \quad: \quad \begin{array}{l}
\text { Diameter of the wound on the first } \\
\text { day }(\mathrm{mm})
\end{array} \\
\mathrm{d}_{\mathrm{x}}: \begin{array}{l}
\text { Diameter of the wound on day } x \\
(\mathrm{~mm})
\end{array}
\end{array}
$$

\section{Ethical clearance}

In this research, white mice were used as experimental animals. This research had been declared as reliable by the Ethical Committee of Medical Research, University of Kader Bangsa No. 001/KEPK/UKB-FKES/VII/2020

\section{RESULT AND DISCUSSION Coffee extract making}

A thick extract was obtained from 500 grams of the simplicia of 28 grams of immature coffee beans and 30 grams of mature coffee beans at a yield percentage of $5.6 \%$ and $6 \%$, respectively. The yield percentage indicated how effective the extraction process was and how much compound was extracted. 
Characteristic test of the physical and chemical properties of cream

The cream dosage was tested for physical and chemical properties, including organoleptic, homogeneity, $\mathrm{pH}$, and spreadability tests. Table 2 presents the result of the organoleptic and homogeneity tests of cream dosage.

Table 2. Organoleptic and homogeneity tests

\begin{tabular}{lllll}
\hline \multicolumn{1}{c}{ Formula } & Color & Odor & Softness & Homogeneity \\
\hline Immature coffee F1 & White & Typical coffee & Soft & Homogeneous \\
\hline Immature coffee F2 & Cream & Typical coffee & Soft & Homogeneous \\
\hline Immature coffee F3 & Light brown & Typical coffee & Soft & Homogeneous \\
\hline Mature coffee F1 & White & Typical coffee & Soft & Homogeneous \\
\hline Mature coffee F2 & Cream & Typical coffee & Soft & Homogeneous \\
\hline Mature coffee F3 & Light brown & Typical coffee & Soft & Homogeneous \\
\hline
\end{tabular}

The result of organoleptic tests of color, odor, texture, and homogeneity showed that ethanol extract cream made from arabica coffee was white, cream, or light brown in color with a typical sense of coffee, soft (semisolid) and not clumping texture, and homogeneous in each cream formula. The result of $\mathrm{pH}$ and spreadability tests is presented in Table 3.

Table 3. $\mathrm{pH}$ and spreadability tests

\begin{tabular}{clcc}
\hline No. & Formula & $\mathrm{pH}$ & Spreadability \\
\hline 1 & F1 mature coffee & 5.4 & 3.5 \\
\hline 2 & F2 mature coffee & 5.5 & 3.5 \\
\hline 3 & F3 mature coffee & 5.7 & 3.6 \\
\hline 4 & F1 immature coffee & 5.3 & 3.8 \\
\hline 5 & F2 immature coffee & 5.4 & 4 \\
\hline 6 & F3 immature coffee & 5.7 & 4 \\
\hline Mean & 5.5 & 3.73 \\
\hline
\end{tabular}

Coffee extract cream had an average $\mathrm{pH}$ of 5.5, thereby meeting the standard $\mathrm{pH}$ of the skin. When the cream $\mathrm{pH}$ was less than 4.5 , the cream was acidic and potential for irritating the skin. Additionally, when it was more than 6.5 , it was alkaline and potential for causing dry and scaly skin (Solanum and Nsp, 2015).

Meanwhile, the spreadability test testified that the greater the spreadability, the better the physical properties of the cream. Recommended spreadability widened the contact between the cream and the skin, accelerating the active substance adsorption. The coffee extract cream had an average spreadability of $3.73 \mathrm{~cm}$. The dispersibility did not meet the standard due to the concentration of extract added. The more the extract added, the more concentrated the consistency of cream dosage, decreasing its spreadability (Ekawati et al., 2012).

\section{Burn wound test}

To identify the percentage of wound recovery, we made a direct observation of the wound area. The measurement of the wound area was carried out in 2-day interval by taking the picture of the wound area which had been scaled using a ruler positioned on the side of the wound. The Image $J^{\circledR}$ application was used to measure the area. The data of wound recovery percentages were then analyzed using SPSS. Table 4 and Figure 1 indicate the resultof the burn wound recovery measurement of all treatment groups from day $0-14$. 


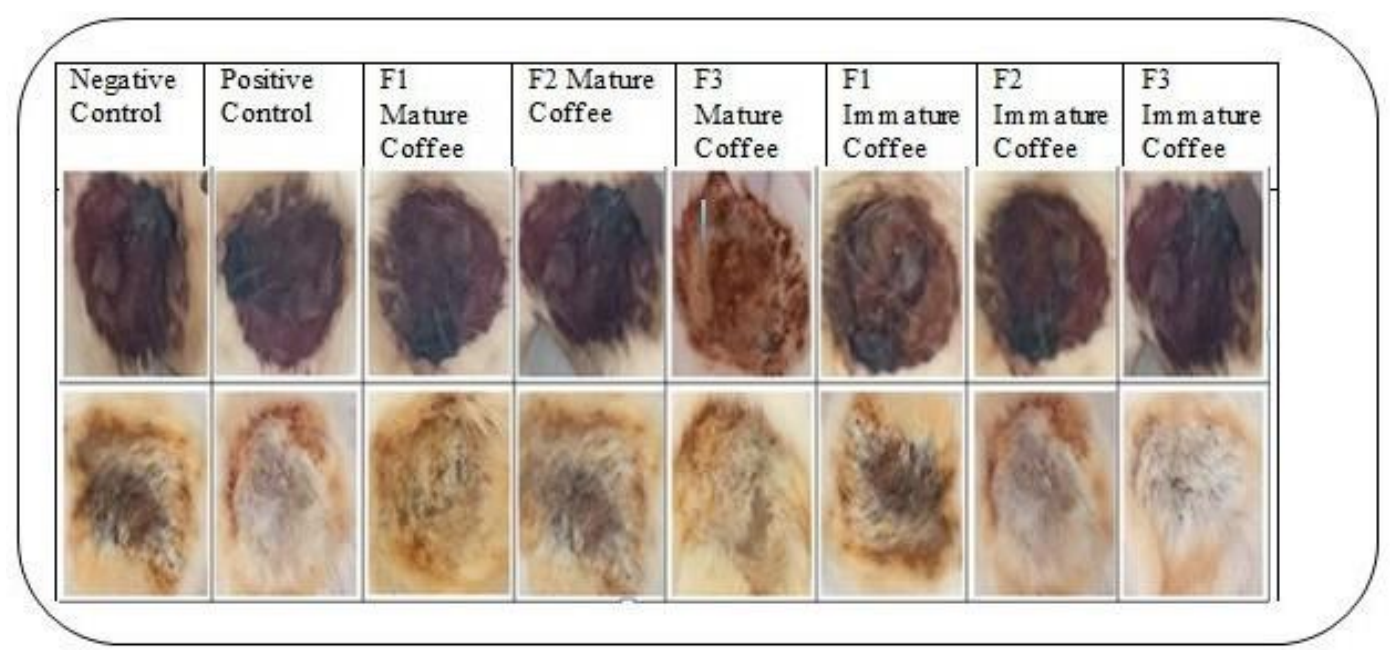

Figure 1: Changes in the diameter of wound area from day 0-14

Table 4. Observation of burn wound recovery

Treatment Group

Average Wound Area $\left(\mathrm{cm}^{2}\right)$ on Day 0

\begin{tabular}{ll}
\hline Positive control & 1.95 \\
\hline Negative control & 1.93 \\
\hline F1 mature coffee $(0.1)$ & 1.94 \\
\hline F2 mature coffee $(0.2)$ & 1.95 \\
F3 mature coffee $(0.3)$ & 1.95 \\
F1 immature coffee $(0.1)$ & 1.94 \\
F2 immature coffee $(0.2)$ & 1.94 \\
F3 immature coffee $(0.3)$ & 1.95 \\
\hline
\end{tabular}

From the first to the sixth day oftreatment, the average percentage of wound recovery for each group showed less than $20 \%$. This is because the wound recovery process was still in the inflammatory phase. The inflammatory phase is a phase susceptible for infection, and the presence of fluid in the injured skin can be a good medium for bacterial growth. Moreover, the release of inflammatory mediators can worsen the infection. In the early wound recovery process, it can form a scab, but the recovery is not optimal yet (Sjamsuhidajat et al., 2011)

The $10^{\text {th }}$ day of wound recovery process showed that the average wound recovery in positive control group was $30 \%$ higher than the negative control group in both immature coffee formula (F3 $(0.3 \%)$, F2 $(0.2 \%), \mathrm{F} 1(0.1)$, and the mature coffee formula $(\mathrm{F} 3(0.3 \%), \mathrm{F} 2(0.2 \%), \mathrm{F} 1(0.1 \%))$ respectively. At this phase, the inflammation had reduced, and the scab had fully formed. And from day 10 to 12, the average percentage of wound recovery significantlyincreased in each treatment. This was because the wound recovery process had entered the remodeling phase. Whereas the percentage of wound recovery in the negativecontrol group slowly increased by $20 \%$ on the $12^{\text {th }}$ day. This was because there was no treatment for the negative control group.

The treatment group F3 mature Coffee (0.3) was the most effective dosage since the $\%$ recovery engendered was $82 \%$, close to that of the positive control which was $95 \%$. Based on the scab parameter, the treatment group F3 mature coffee (0.3) shared similarities in the scab formation which occurred on Day 3. The scab recovery time was faster in the treatment group III than that in the positive control group due to the content of coffee extract which acceleratedthe process of burn wound recovery in the proliferation process. In the maturation phase, the percentage of wound recovery significantly increased. Besides, the factor of burn wound recovery was not only the high content of active substances but also the wound area and responses given by each individual (Tiwari, 2012).

The process of wound recovery could be examined using several parameters, one of which was scab formation. Scab formation burn wounds indicated that the wound 
recovery process was entering an early stage of proliferation (Akhoondinasab et al., 2014). Scab formed covered and protected thewound from further microbial contamination in the wound area. During the scab recovery, new skin cells were growing and helping to close the woundedges (Aponno et al., 2014).

The analysis of burn wound recovery shows that coffee extract has a recovery impact on burn wound in the inflammatory and proliferation phases, induced by flavonoid compounds contained in the coffee extract which has anti-inflammatory and antibacterial effects. Flavonoid compounds in coffee beans are anti-inflammatory and thereby reducing inflammation and pain due to bleeding or swelling on the wound. Flavonoid inhibits cyclooxygenase (COX) and lipoxygenase which can inhibit leukotriene and prostaglandin syntheses, reduce the body's responses to inflammation, and reduce the release of arachidonicacid by neutrophils to the wound area (Riansyah etal., 2015).

Based on the results of the KolmogorovSmirnov normality test, the immature coffee and the mature coffee formula have normal data distribution with $\mathrm{p}$ value of 0.962 and 0.666 so that it can be continued for the One Way Anova test.

Based on the results of One-Way Anova test analysis on the mature coffee formula, there is no significant of burn diameter among the five treatments with $\mathrm{p}$ value $=0.063$. In contrast, the immature coffee formula shows that the burn diameter is significantly different among the five treatments with $\mathrm{p}$ value of 0.011 . Furthermore, from further analysis by Tukey HSD, only positive control and mature coffee $\mathrm{F} 3$ formula $(0,3 \%)$ have significant difference with negative control with $\mathrm{p}$ value of 0.041 and 0.010 . The finding shows that the minimum concentration of mature coffee bean extract that can affect burn healing is $0.3 \%$.

\section{CONCLUSION}

In conclusion, the ethanol extract of mature and immature coffee beans had a recovery impact on the burn wound of male white mice (Mus musculus).
In terms of concentration, $0.3 \%$ of old coffee powder was more effective to recover burn wounds of male white mice (Mus Musculus), with a wound recovery rate close to that of positive control (burnazin).

\section{ACKNOWLEDGEMENT}

The author would like to thank the Ministry of Education and Culture for the Beginning Lecturers' Research (PDP) grant in 2020 and pharmacy laboratory Kader Bangsa University which had provided research facilities and infrastructures.

\section{REFERENCES}

Akhoondinasab, M.R., Akhoondinasab, M., Saberi, M., 2014. Comparison of healing effect of aloe vera extract and silver sulfadiazine in burn injuries in experimental rat model. World journal of plastic surgery, 3(1), 29-34.

Aponno, J.V, Yamlean, P.V.Y., Supriati, H.S., 2014. Uji Efektivitas Sediaan Gel Ektrak Etanol Daun Jambu Biji (Psidium guajava Linn) Terhadap Penyembuhan Luka Yang Terinfeksi Bakteri Staphylococus aureus Pada Kelinci (Orytolagus cuniculus). Pharmacon, 3(3), 279-286.

Depkes RI, 2013. Riset kesehatan dasar, Badan Penelitian dan Pengembangan Kesehatan Kementerian Kesehatan RI, Indonesia.

Ekawati, K., Naniek, W., Mimiek, M., Syarifatun, K., 2012. Pengaruh konsentrasi ekstrak etanolik Daun Teh Hijau (Camellia Sinesis L.) dalam sediaan krim terhadap sifat fisik dan aktivitas antibakteri. Sains medika journal of health and medicine, 4(2), 147-156.

Elmitra, 2017. Buku Dasar-dasar Farmasetika dan Sediaan Semi Solid. Deepublish, Bengkulu.

Juwita, A.P., Yamlean, P.V.Y., Edy, H.J., 2013. Formulasi Krim Ektrak Etanol Daun Lamun (Syringodium isoetifolium) 2(02), 8-13. 
Muljana, W., 2010. Bercocok Tanam Kopi. Aneka Ilmu, Semarang.

Murrukmihadi, M., Ananda, R., Handayani, T.U., 2012. Sediaan Krim Ekstra Etanolk Bunga Terhadap Sifat Fisik Dan Aktifitas Antibakteri Pada Staphylococcus aureus Effect of Carbomer 934 and Cetyl Alcohol Addittion as Emulsifier in Ethanolic Extract Hibiscus (Hibiscus rosa-sinenis L.) Cream on the Physical. Majalah Farmaseutik, 8(2), 152-157.

Nugroho, T., 2012. Luka Bakar \& Artritis Reumatoid. Nuha Medika, Yogyakarta.

Paputungan, W.A., Lolo, W.A., Siampa, J.P., 2019. Aktivitas Antibakteri dan Analisis KLT- Bioautografi Dari Fraksi Biji Kopi Robusta (Coffea canephora Pierre ex A. Froehner). Pharmacon Jurnal Ilmiah Farmasi, 8(3), 100-108.

Puspitasari, A.D., Yuita, N.E., Sumantri, S., 2017. Krim Antioksidan Ektrak Etanol Daun Kopi Arabika (Coffea Arabica). Jurnal Ilmiah Teknosains, 3(2), 1-7.

Riansyah, Y., Mulqie, L., Choesrina, R., 2015. Uji Aktivitas Antiinflamasi Ekstrak Etanol Daun Ubi Jalar Ungu (Ipomoea batatas (L.) Lamk) terhadap Tikus Wistar Jantan, Prosiding Penelitian SpeSIA, Unisaba, 1(2), 630636.

Sembiring, B.B., Ma'mun, Ginting, E.I.,2015. Pengaruh Kehalusan Bahan dan Lama Ektraksi Terhadap Mutu Ektrak Tumulawak (Curcuma xanthorriza Roxb). Buletin Penelitian Tanaman Rempah dan Obat, 17(2), 53-58.

Sjamsuhidajat, R., W.D.J., 2013. Buku Ajar Ilmu Bedah, Ed.3. CGC, Jakarta, Indonesia.

Solanum, L., Nsp, A.S., 2015. Antioxidant Activity Of Cream Dosage Form Of Tomato Extract (Solanumlycopersicum L.). Traditional Medicine Journal, 18(3), 132-140.
Sukmawati, E., 2018. Faktor - Faktor Yang Berhubungan Dengan Proses Penyembuhan Luka Post Sectio caesaria. Journal of Economics, Business \& Accountancy Ventura, 21(10), 1-9.

Tiwari, V.K., 2012. Burn wound: How it differs from other wounds. Indian Journal of Plastic Surgery, 45(2), 364 373.

Wijaya, B.A., Citraningtyas, G. Wehantouw, F., 2014. Potensi Ekstrak Etanol Tangkai Daun Talas (Colocasia esculenta [L]) Sebagai Alternatif Obat Luka Pada Kulit Kelinci (Oryctolagus cuniculus). Pharmacon, 3(3), 2302-2493.

Wirastuty, R.Y., 2016. Uji Efektivitas Gel Ekstrak Etanol Kulit Batang Kayu Jawa (Lannea coromandelica) Pada Kelinci (Oryctolagus cuniculus) Sebagai Obat Penyembuhan Luka Bakar. Journal of Pharmaceutical Science and Herbal Technology, 1(1), 32-35.

Yuwono, H.S., 2014. The New Paradigm of Wound Management Using Coffee Powder. Global Journal of Surgery, 2(2), 25-29. 